\title{
Article \\ Bioactive Phytochemicals from Mulberry: Potential Anti-Inflammatory Effects in Lipopolysaccharide-Stimulated RAW 264.7 Macrophages
}

\author{
Dahae Lee ${ }^{1, \dagger}$, Seoung Rak Lee ${ }^{2, \dagger}$, Ki Sung Kang ${ }^{1, *}$ and Ki Hyun Kim ${ }^{2, * \mathbb{C}}$ \\ 1 College of Korean Medicine, Gachon University, Seongnam 13120, Korea; pjsldh@gachon.ac.kr \\ 2 School of Pharmacy, Sungkyunkwan University, Suwon 16419, Korea; davidseoungrak@gmail.com \\ * Correspondence: kkang@gachon.ac.kr (K.S.K.); khkim83@skku.edu (K.H.K.); Tel.: +82-31-750-5402 (K.S.K.); \\ $+82-31-290-7700$ (K.H.K.) \\ + These authors contributed equally to this study.
}

Citation: Lee, D.; Lee, S.R.; Kang, K.S.; Kim, K.H. Bioactive

Phytochemicals from Mulberry:

Potential Anti-Inflammatory Effects in Lipopolysaccharide-Stimulated RAW 264.7 Macrophages. Int. J. Mol. Sci. 2021, 22, 8120. https://doi.org/ $10.3390 /$ ijms 22158120

Academic Editor: Amélia M. Silva

Received: 31 May 2021

Accepted: 28 July 2021

Published: 29 July 2021

Publisher's Note: MDPI stays neutral with regard to jurisdictional claims in published maps and institutional affiliations.

Copyright: (c) 2021 by the authors. Licensee MDPI, Basel, Switzerland. This article is an open access article distributed under the terms and conditions of the Creative Commons Attribution (CC BY) license (https:/ / creativecommons.org/licenses/by/ $4.0 /)$.

\begin{abstract}
The fruits of the mulberry tree (Morus alba L.), known as white mulberry, have been consumed in various forms, including tea, beverages, and desserts, worldwide. As part of an ongoing study to discover bioactive compounds from M. alba fruits, the anti-inflammatory effect of compounds from M. alba were evaluated in lipopolysaccharide (LPS)-stimulated mouse RAW 264.7 macrophages. Phytochemical analysis of the ethanol extract of the M. alba fruits led to the isolation of 22 compounds. Among the isolated compounds, to the best of our knowledge, compounds 1, 3, 5, 7, 11, 12, and 14-22 were identified from M. alba fruits for the first time in this study. Inhibitory effects of 22 compounds on the production of the nitric oxide (NO) known as a proinflammatory mediator in LPS-stimulated RAW 264.7 macrophages were evaluated using NO assays. Western blot analysis was performed to evaluate the anti-inflammatory effects of cyclo(L-Pro-L-Val) (5). We evaluated whether the anti-inflammatory effects of cyclo(L-Pro-L-Val) (5) following LPS stimulation in RAW

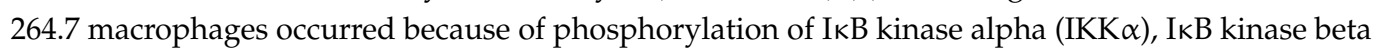
$(\mathrm{IKK} \beta)$, inhibitor of kappa B alpha $(\mathrm{I} \kappa \mathrm{B} \alpha)$, nuclear factor kappa B (NF- $\kappa \mathrm{B})$ and activations of inducible nitric oxide synthase (iNOS), and cyclooxygenase-2 (COX-2). Cyclo(L-Pro-L-Val) (5) significantly suppressed phosphorylations of IKK $\alpha, \operatorname{IKK} \beta, \operatorname{I\kappa B} \alpha$, and NF- $\mathrm{B}$ and activations of iNOS and COX-2 in a concentration-dependent manner. Taken together, these results indicate that cyclo(L-Pro-L-Val) (5) can be considered a potential therapeutic agent for the treatment of inflammation-associated disorders.
\end{abstract}

Keywords: Morus alba; inflammation; nitric oxide; nuclear factor kappa B; inducible nitric oxide synthase; cyclooxygenase-2

\section{Introduction}

Inflammation is a complex physiological response to foreign harmful stimuli including particles, toxic compounds, bacteria, and viruses. In the host defense system of macrophages, the regulation of inflammation is involved in immune function [1]. In response to lipopolysaccharide (LPS), macrophages overproduce proinflammatory mediator nitric oxide (NO) and cyclooxygenase (COX-2) to upregulate inflammatory states. NO is synthesized by inducible nitric oxide synthase (iNOS) via the NF-kB signaling pathway. Therefore, inhibition of LPS production and related mechanisms are considered useful targets in research to discover potential anti-inflammatory compounds [2].

The fruits of mulberry tree (Morus alba L.) belonging to the family of Moraceae are known as white mulberry, which is popularly consumed in various forms, including tea, beverages, and desserts, worldwide [3]. In Korea and China, where this plant is harvested, the leaves of $M$. alba have been traditionally used as a fodder for silkworms, as well as a medicinal herb to treat diabetes and improve eyesight [4]. The pharmacological activities of 
M. alba have also been actively studied, with reports that the white mulberry has a number of beneficial effects such as antioxidant [5-7], anti-microbial [8], anti-obesity [9,10], and anti-inflammatory activities [7].

As part of a continuing research project to discover bioactive natural products, our group has investigated biologically active and structurally interesting compounds from the ethanol extract of fruits of M. alba $[7,11-14]$. In our previous study, we observed that butyl pyroglutamate identified from the fruits of $M$. alba exhibits protective effects against apoptosis, characteristic of cisplatin-induced kidney cell damage [11]. Our previous research has also shown that indole acetic acid derivative in $M$. alba induces apoptosis via both death receptor-mediated extrinsic pathway and mitochondria-mediated intrinsic pathway [12]. Odisolane, a new oxolane derivative identified from $M$. alba, was found to inhibit the tube formation of human umbilical vein vascular endothelial cells via vascular endothelial growth factor-mediated mechanistic pathway [13]. In addition, loliolide in $M$. alba was demonstrated by our group to protect INS-1 human pancreatic $\beta$-cells against apoptosis triggered by streptozotocin [14]. In particular, our recent research on ethanol extract from mulberry fruits reported its inhibitory effect on LPS-stimulated NO production and iNOS expression in a mouse macrophage cell line (RAW 264.7), suggesting its potential for anti-inflammatory effect [7]. In the present study, the ethanol extract of $M$. alba fruits was further investigated to identify potential anti-inflammatory compounds. Phytochemical analysis of the extract of $M$. alba fruits led to the identification of 22 compounds (1-22). Their structures were determined by detailed analysis of their nuclear magnetic resonance (NMR) spectroscopic and physical data as well as mass spectrometry (MS) data from liquid chromatography-mass spectrometry (LC-MS) analysis. Herein, we report the isolation and structural identification of the compounds (1-22) and their anti-inflammatory potential in RAW 264.7 cells and basic underlying mechanism of action.

\section{Results}

\subsection{Isolation and Identification of the Compounds}

Dried and smashed M. alba fruits were extracted using $70 \%$ aqueous ethanol three times and filtered at room temperature. The filtrate was evaporated in vacuo to obtain a crude ethanol extract. The ethanol extract was solvent-partitioned with hexane, $\mathrm{CH}_{2} \mathrm{Cl}_{2}$, EtOAc, and $n-\mathrm{BuOH}$ to obtain four fractions. TLC and LC/MS analysis of solvent fractions determined that the $\mathrm{CH}_{2} \mathrm{Cl}_{2}$-soluble fraction could be the main fraction showing a chemical profile with plentiful structural diversity. Phytochemical analysis of the $\mathrm{CH}_{2} \mathrm{Cl}_{2}$ fraction was carried out using repeated column chromatography and preparative/semipreparative HPLC, which afforded 22 compounds (1-22) (Figure 1). The structures of the isolated compounds including their absolute configurations were determined to be grasshopper ketone (1) [15], dihydroconiferyl alcohol (2) [16], threo-guaiacylglycerol- $\beta$-O4'-dihydroconiferyl alcohol (3) [17], L-proline (4) [18], cyclo(L-Pro-L-Val) (5) [19], methyl benzoate (6) [20], cyclo(L-Ala-L-Val) (7) [21], vanillic acid (8) [21], tyrosol (9) [22], 3-hydroxy1-(4-hydroxyphenyl)-1-propanone (10) [23], (E,Z)-13-hydroxy-9,11-heptadecadienoic acid (11) [24], 7 $\beta$-hydroxysitosterol (12) [25], 7-ketositosterol (13) [26], stigmast-4-en-3 $\beta$-ol-6one (14) [27], (3 $\beta, 6 \alpha)$-stigmast-4-ene-3,6-diol (15) [28], stigmast-4-ene-3 $\beta, 6 \beta$-diol (16) [29],

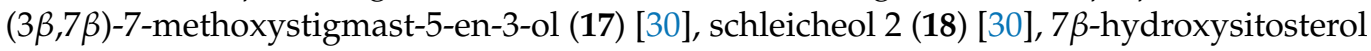
3 -O- $\beta$-D-glucoside (19) [25], portulacerebroside B (20) [31], $7 \alpha$-hydroxysitosterol 3-O- $\beta$ D-glucoside (21) [25], and (24S)-24-Ethylcholesta-7,22-diene-3 $\beta, 5 \alpha, 6 \beta$-triol (22) [32] by comparing their NMR and physical data such as optical rotation value with those reported in the literature. In particular, the absolute configurations of the amino acid units in $\mathbf{5}$ were confirmed by the Marfey's method [33]. The hydrolysis products of 5 were subjected to L-FDAA derivatization and analyzed by electrospray ionization (ESI)-quadrupole-time of flight (Q-TOF)-liquid chromatography (LC)/mass spectrometry (MS) (see Supplementary Materials), which showed that all amino acid residues were L-configurations in 5 (Figures S25-S31). Among the isolated compounds, to the best our knowledge, compounds $1,3,5,7,11,12$, and 14-22 were identified from M. alba fruits for the first time in this study. 
<smiles>CC(=O)/C=C/C1=C(C)C(C)(C)C[C@](C)(O)C1</smiles>

1<smiles>O=C(O)C1CCCN1</smiles>

4<smiles>OCCc1ccc(O)cc1</smiles>

9<smiles>COc1cc(CCCO)ccc1O</smiles>

2<smiles>CC(=O)c1ccccc1</smiles>

6<smiles>COc1cc([C@@H](O)[C@H](CO)Oc2ccc(CCCO)cc2OC)ccc1O</smiles><smiles>CC(C)[C@H]1NC(=O)[C@@H]2CCCN2C1=O</smiles>

5<smiles>CC(C)[C@H]1NC(=O)[C@H](C)NC1=O</smiles>

7<smiles>COc1cc(C(=O)O)ccc1O</smiles>

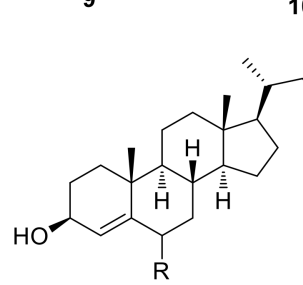

$14 \mathrm{R}=\mathrm{O}$ $15 \mathrm{R}=\alpha-\mathrm{OH}$ $16 \mathrm{R}=\beta-\mathrm{OH}$<smiles>CCCCCCCCCC/C=C/CCCC[C@H](O)[C@H](COC1O[C@H](CO)[C@@H](O)[C@H](O)[C@H]1O)NC(=O)[C@H](O)CCCCCCCCCCCC</smiles>

20<smiles>CCCC[C@H](O)/C=C\C=C/CCCCCCC(=O)O</smiles>

11

10<smiles>[R]C1C=C2C[C@@H](O)CC[C@]2(C)[C@H]2C[C@@H]3CCCC[C@H]3[C@H]12</smiles>

\12 $12=\beta-\mathrm{OH}$

$13 \mathrm{R}=\mathrm{O}$

$17 \mathrm{R}=\beta-\mathrm{OCH}_{3}$

$18 \mathrm{R}=\alpha-\mathrm{OCH}_{3}$

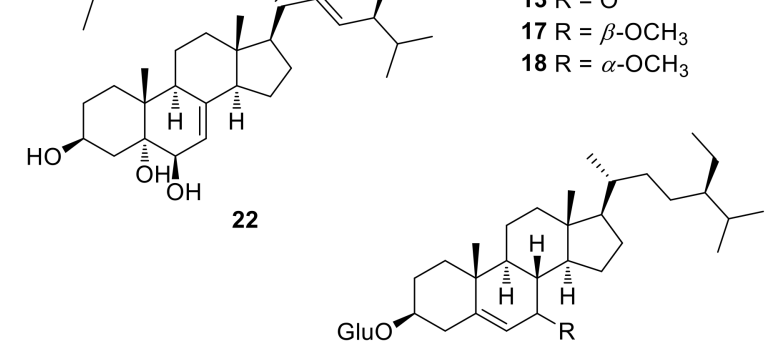

$19 \mathrm{R}=\beta-\mathrm{OH}$

$21 \mathrm{R}=\alpha-\mathrm{OH}$

Figure 1. Chemical structures of compounds 1-22 isolated from M. alba fruits.

\subsection{Effects of Compounds 1-22 on Nitric Oxide (NO) Production}

The non-toxic dose of compounds 1-22 was determined using a cell viability assay on RAW 264.7 macrophages. Some compounds excluding 5, 13, 15, 16, 17, 18, and 19 were cytotoxic, as cell viability decreased to below $80 \%$ (Figure 2). The inhibitory effects of compounds 1-22 on NO production in LPS-activated RAW 264.7 macrophages were investigated. Among these compounds, only compound $\mathbf{5}$ attenuated nitrite concentration in LPS-activated RAW 264.7 cells. As shown in Figure 3E, compared with the LPS-only group $(23.20 \pm 0.58 \mu \mathrm{M})$, coincubation with compound $5(25 \mu \mathrm{M}, 50 \mu \mathrm{M}$, and $100 \mu \mathrm{M})$ and LPS resulted in a $15.81 \pm 0.43 \mu \mathrm{M}, 14.31 \pm 0.48 \mu \mathrm{M}$, and $12.56 \pm 0.27 \mu \mathrm{M}$, respectively, lower nitrite concentration. As shown in Figure 3W, compared with the LPS-only group $(19.75 \pm 0.34 \mu \mathrm{M})$, coincubation with $N^{\mathrm{G}}$-methyl-L-arginine acetate salt (L-NMMA) $(25 \mu \mathrm{M}, 50 \mu \mathrm{M}$, and $100 \mu \mathrm{M})$ and LPS resulted in a $15.58 \pm 0.27 \mu \mathrm{M}, 13.99 \pm 0.29 \mu \mathrm{M}$, and $11.33 \pm 0.39 \mu \mathrm{M}$, respectively, lower nitrite concentration. These results suggest that compound 5 might have potential anti-inflammatory activity that was comparable to L-NMMA in LPS-activated RAW 264.7 cells. In addition, considering the result of cell viability after treatment with compound 5, its inhibitory effect on nitrite concentration in LPS-activated RAW 264.7 cells was deemed not to be attributable to its cytotoxicity. 


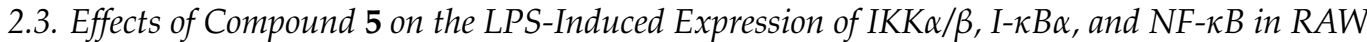
264.7 Mouse Macrophages

To confirm that compound 5 might be correlated with the inhibition of protein expression of I $\kappa B$ kinase alpha and beta $(\mathrm{IKK} \alpha / \beta)$, inhibitor of kappa $B$ alpha $(\mathrm{I}-\mathrm{k} B \alpha)$, and nuclear factor kappa B (NF-kB), we performed Western blot analysis. When the RAW264.7 cells were stimulated with LPS $(1 \mu \mathrm{g} / \mathrm{mL})$ for $24 \mathrm{~h}$, the protein expression of IKK $\alpha / \beta$, $\mathrm{I}-\kappa \mathrm{B} \alpha$, and NF- $\mathrm{kB}$ was increased. However, treatment with compound 5 at $50 \mu \mathrm{M}$ and $100 \mu \mathrm{M}$ significantly inhibited expression of IKK $\alpha / \beta, \mathrm{I}-\mathrm{k} B \alpha$, and NF- $\mathrm{kB}$ in a concentration dependent manner (Figure 4).

(A)
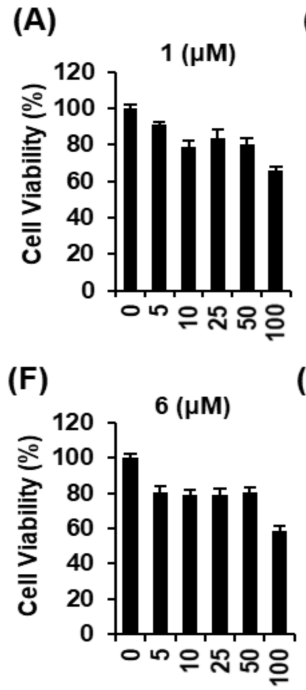

(B)
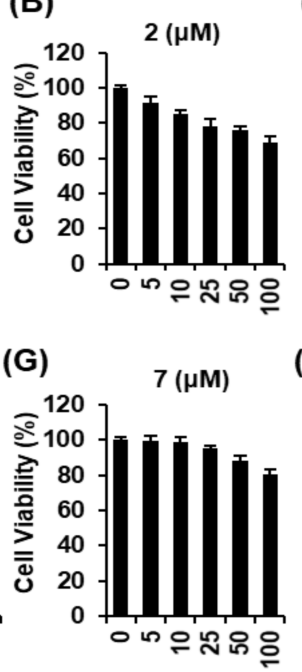

(K)

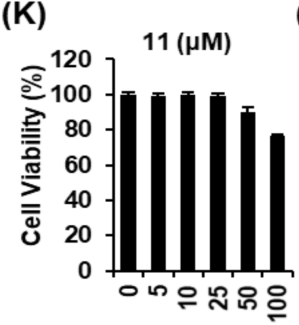

(L)

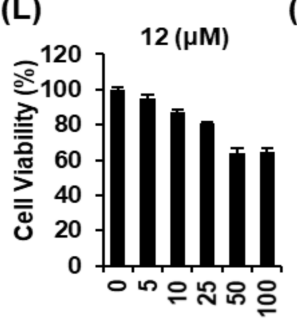

(P)

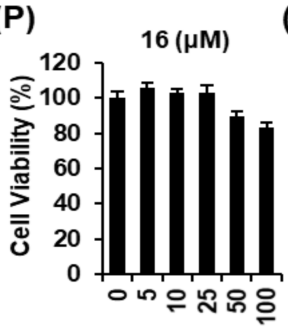

(Q)

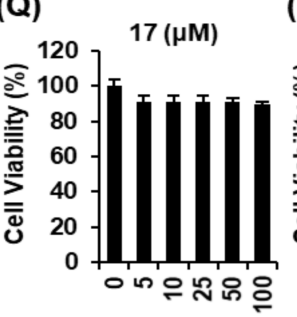

(C)

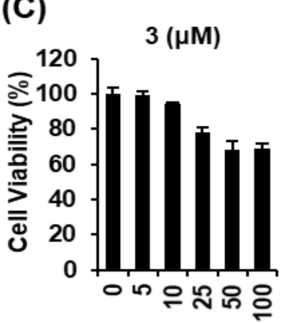

(H)

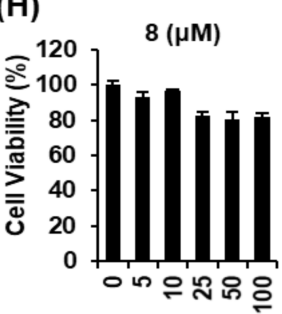

(I)

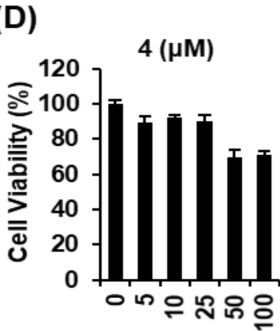

(E)

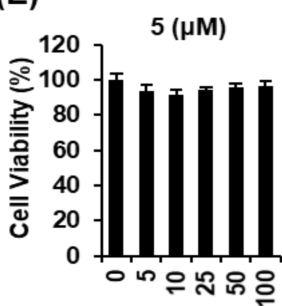

(I)

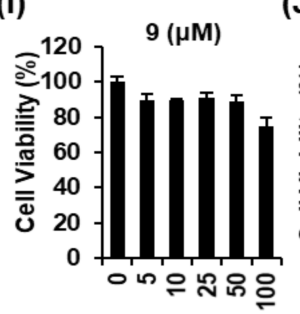

(J)

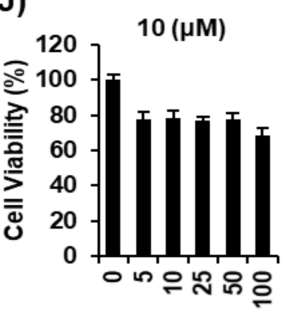

(N)
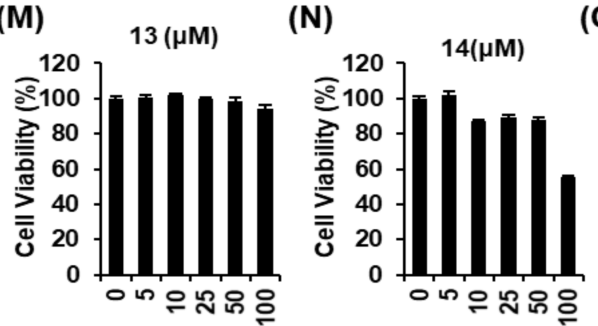

(O)

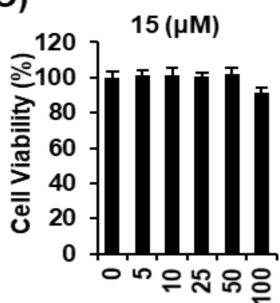

(R)

(S)

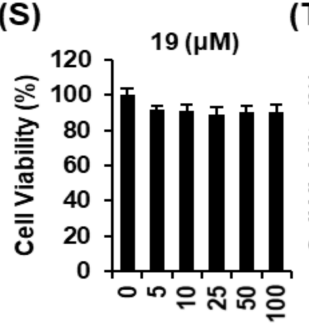

(T)

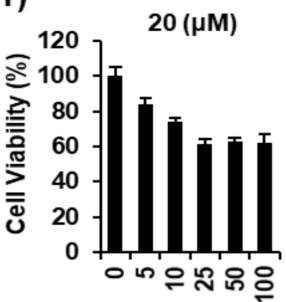

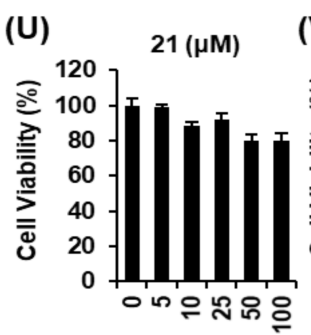

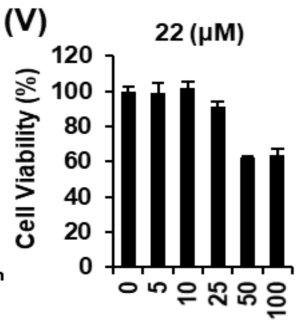

Figure 2. Effects of compounds 1-22 isolated from M. alba fruits on the viability of RAW 264.7 mouse macrophages. Effect of (A-V) compounds 1-22, compared with the control $(0 \mu \mathrm{M})$, on the viability of RAW 264.7 mouse macrophages for $24 \mathrm{~h}$ by MTT assay. 
(A)

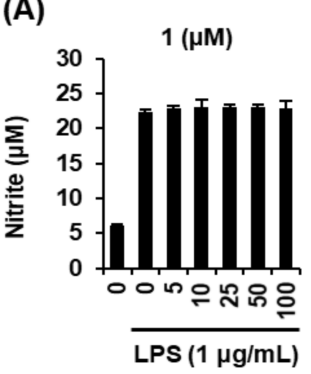

(F)

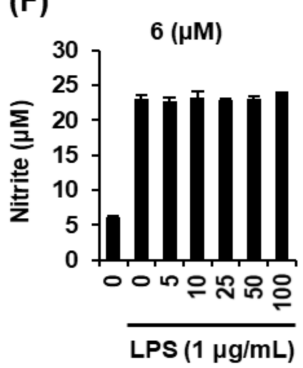

(K)

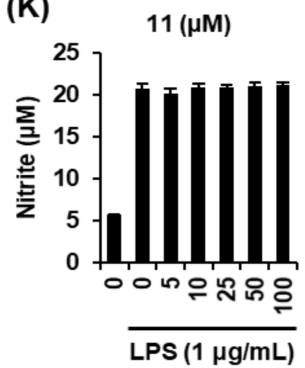

(P)

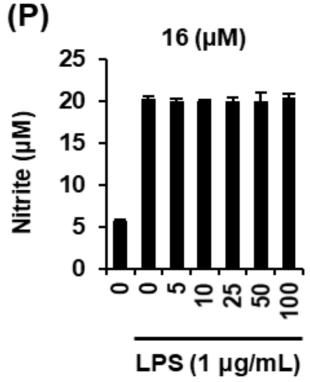

(U)

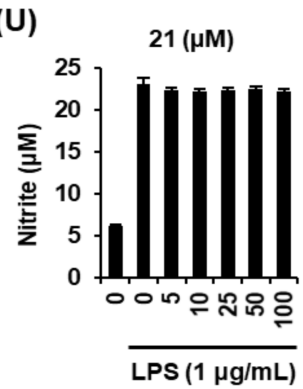

(B)

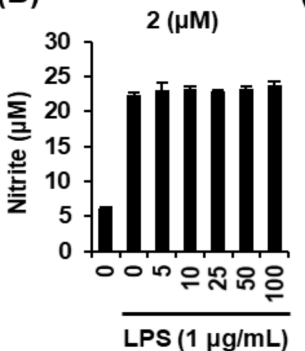

(G)

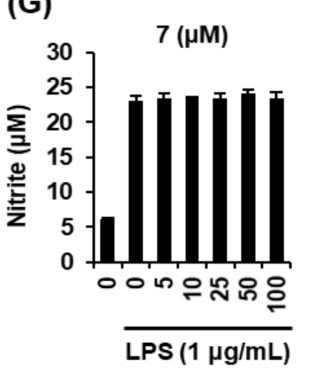

(L)

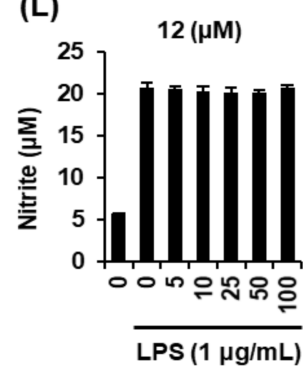

(Q)

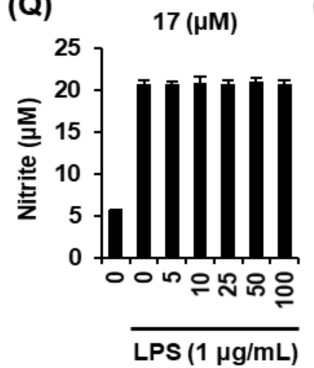

(V)

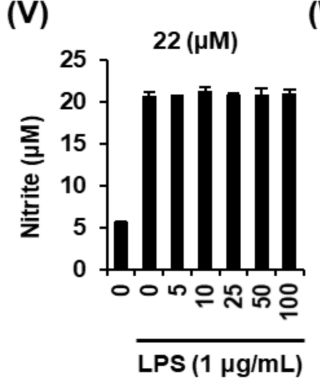

(C)

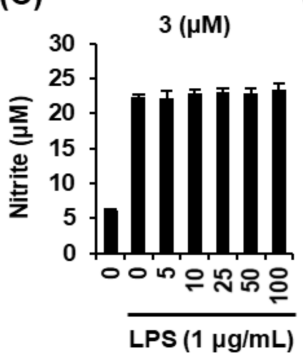

(H)

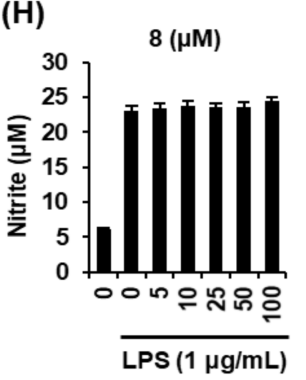

(M)

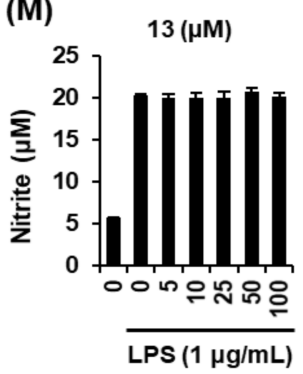

(R)

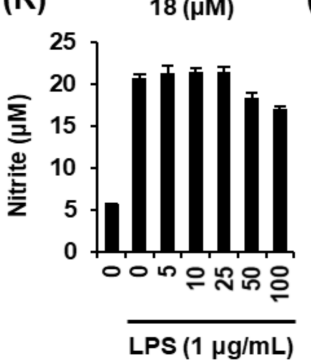

(E)

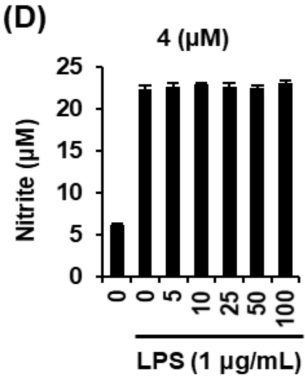

(I)

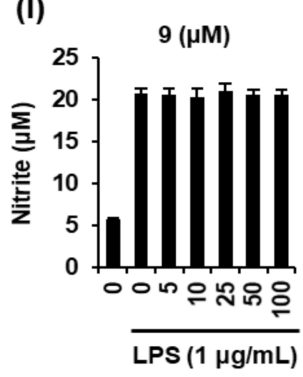

(J)
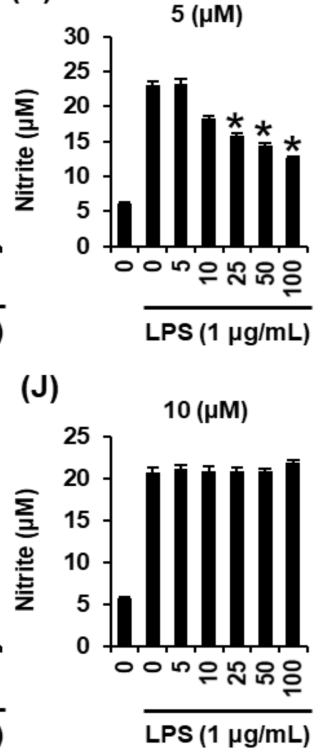

(N)

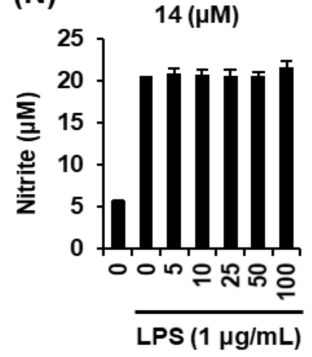

(O)

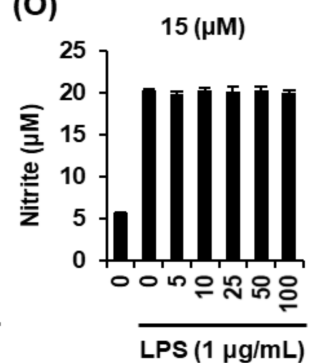

(S)

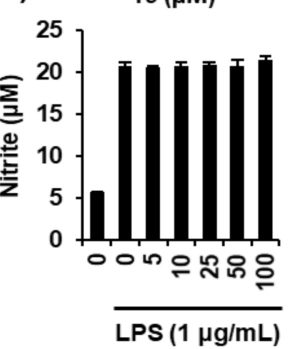

(T)

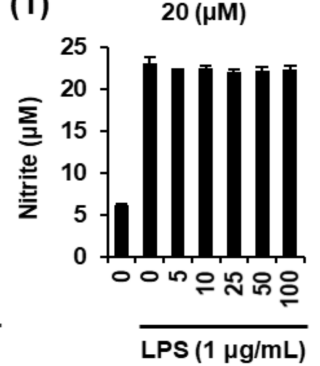

(W)

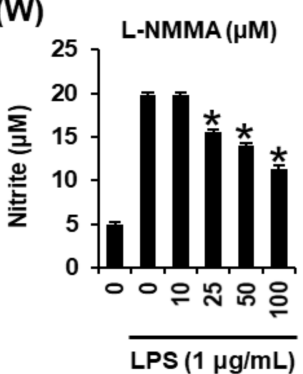

Figure 3. Effects of compounds 1-22 isolated from $M$. alba fruits and $N^{\mathrm{G}}$-methyl-L-arginine acetate salt (L-NMMA) on the nitric oxide (NO) production in RAW 264.7 mouse macrophages treated with lipopolysaccharide (LPS). (A-W) The effects of compounds 1-22 and the nitric oxide (NO) synthase inhibitor L-NMMA in RAW 264.7 mouse macrophages treated with LPS were investigated (mean $\pm \mathrm{SD},{ }^{*} p<0.05$ compared to group treated with $1 \mu \mathrm{g} / \mathrm{mL}$ LPS alone). 
(A)

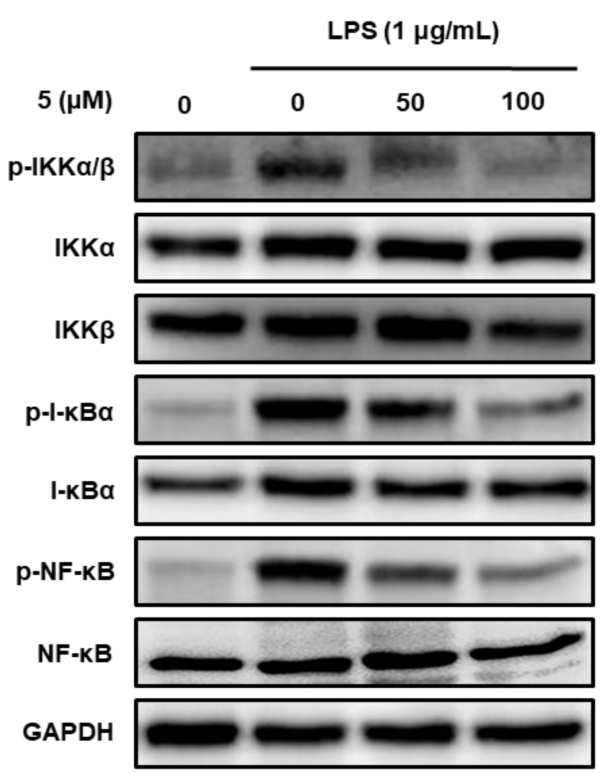

(B)

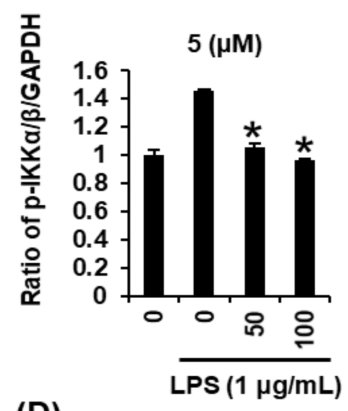

(D)

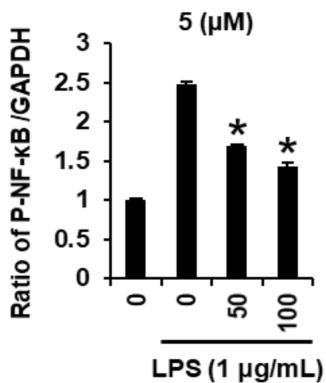

(C)

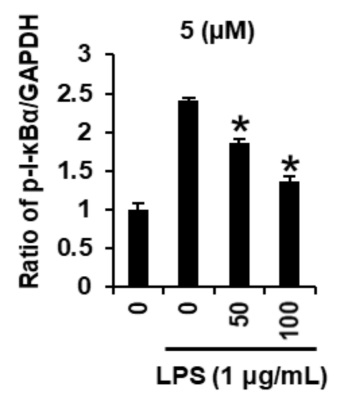

Figure 4. Effects of compound 5 on the expression of IкB kinase alpha and beta (IKK $\alpha / \beta)$, inhibitor of kappa B alpha $(\mathrm{I}-\mathrm{kB} \alpha$ ), and nuclear factor kappa B (NF- $\mathrm{KB}$ ) in RAW 264.7 mouse macrophages treated with lipopolysaccharide (LPS). (A) Representative Western blots showing protein expressions of IKK $\alpha / \beta$, phospho-IKK $\alpha / \beta$ (p-IKK $\alpha / \beta)$, I-KB $\alpha$, phospho$\mathrm{IKK} \alpha / \beta$ (p-I-kB $\alpha), \mathrm{NF}-\mathrm{kB}$, and glyceraldehyde-3-phosphate dehydrogenase (GAPDH). (B-D) Quantitative bar chart for each protein's expression level (mean $\pm \mathrm{SD},{ }^{*} p<0.05$ compared to group treated with $1 \mu \mathrm{g} / \mathrm{mL}$ LPS alone).

\subsection{Effects of Compound 5 on the LPS-Induced Expression of iNOS and COX-2 in RAW 264.7 Mouse Macrophages}

As a result of conducting a follow-up experiment based on the above results, we found that the protein expression of iNOS and COX-2 was increased after stimulation with LPS $(1 \mu \mathrm{g} / \mathrm{mL})$ for $24 \mathrm{~h}$, whereas treatment with compound 5 at $50 \mu \mathrm{M}$ and $100 \mu \mathrm{M}$ significantly inhibited this overexpression in a concentration dependent manner in RAW264.7 cells (Figure 5).

(A)

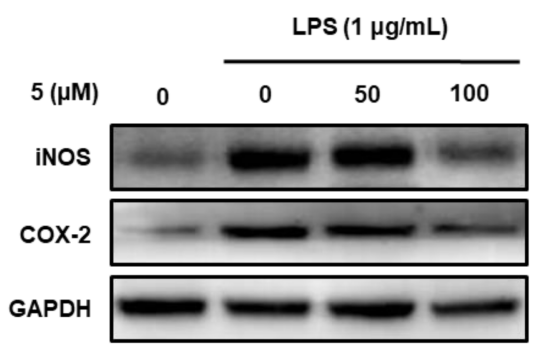

(B)

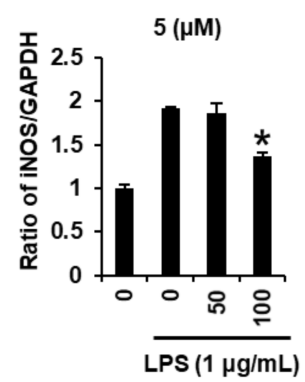

(C)

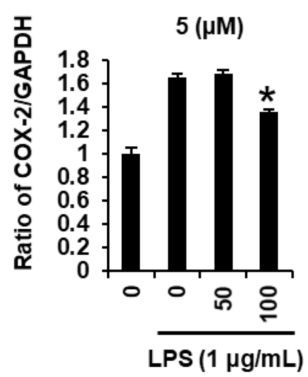

Figure 5. Effects of compound 5 on the expression of inducible nitric oxide synthase (iNOS) and cyclooxygenase-2 (COX-2) in RAW 264.7 mouse macrophages treated with lipopolysaccharide (LPS). (A) Representative Western blots showing protein expressions of iNOS, COX-2, and glyceraldehyde-3-phosphate dehydrogenase (GAPDH). (B,C) Quantitative bar chart for each protein's expression level (mean $\pm \mathrm{SD},{ }^{*} p<0.05$ compared to group treated with $1 \mu \mathrm{g} / \mathrm{mL}$ LPS alone). 


\section{Discussion}

Many studies have been performed with respect to the anti-inflammatory activity of extract of the mulberry fruit (Morus alba L.) [7,34-37]. In contrast, studies on which compounds in mulberry fruit have anti-inflammatory activity are still lacking.

In our previous study, the anti-inflammatory activity of the ethanol extract of the mulberry fruit was reported [7]. As an extension of previous research, our present study performed phytochemical analysis to isolate 22 chemical constituents from the ethanol extract and their non-toxic concentrations were investigated in RAW 264.7 macrophages. In addition, the inhibitory effect on LPS-stimulated NO production and its underlying molecular mechanism were investigated in RAW 264.7 macrophages. Kang et al. recently reported the inhibitory effect of cyclo(L-Pro-D-Val) on LPS-induced endothelial inflammatory responses [38], but they used different cells from ours, and the related mechanistic studies have not yet been conducted. In the present study, the anti-inflammatory action of cyclo(L-Pro-L-Val) and its mechanism of action were evaluated. These results could be a potential scaffold for the development of therapeutic agents to treat inflammatory disorders.

During the inflammatory response to LPS, RAW 264.7 macrophages play a central role in a regulating overproduction of a pro-inflammatory mediator, $\mathrm{NO}$, in cell-based models of inflammation [39]. In this study, compound 5 markedly inhibited the NO production in a concentration-dependent manner in LPS-treated RAW 264.7 cells. Interestingly, its inhibitory effect was similar to that of L-NMMA. L-NMMA is an inhibitor of NO synthesis [40]. There was a report that evaluated the inhibitory effect of L-NMMA on expressions of IKK $\alpha / \beta, \mathrm{I}-\kappa \mathrm{B} \alpha, \mathrm{NF}-\mathrm{KB}$, and iNOS in LPS-treated RAW 264.7 cells [41].

In response to LPS, IKK composed of two catalytic subunits (IKK $\alpha$ and IKK $\beta$ ) are phosphorylated [42]. Phosphorylation of both IKK $\alpha$ and IKK $\beta$ leads to IKB phosphorylation, which directly contributes to activation of a nuclear transcription factor, NF- $\mathrm{kB}$ [43]. $\mathrm{NF}-\mathrm{kB}$ regulates the transcription of iNOS and COX-2 by binding to specific DNA sequences. Induction of iNOS and COX-2 produces NO and prostaglandin E2 (PGE2), respectively [44]. Thus, we investigated whether compound 5 could inhibit expressions of $\mathrm{IKK} \alpha / \beta, \mathrm{I}-\mathrm{kB} \alpha, \mathrm{NF}-\mathrm{kB}$, iNOS, and COX-2 in LPS-treated RAW 264.7 cells using Western blot analysis. Our studies demonstrate that compound 5 in a concentration-dependent manner inhibited LPS-mediated overexpressed IKK $\alpha / \beta, \mathrm{I}-\mathrm{kB} \alpha$, and NF- $\mathrm{KB}$ in RAW264.7 cells. In addition, increased expression of the iNOS and COX-2 was observed in response to LPS stimulation which was inhibited after treatment with compound 5 . These results indicated that compound 5 inhibited the expression of iNOS and COX-2 via inhibition of NF- $\mathrm{kB} / \mathrm{I}-\mathrm{kB} \alpha$ pathway, thus lower expression of iNOS resulted in lower NO production (Figure 5). Although more experiments including animal research are needed to clarify effect bioavailability and bio-accessibility, compound $\mathbf{5}$ has potential as a favorable candidate for the treatment of inflammatory diseases.

\section{Materials and Methods}

\subsection{General Experimental Procedures}

Optical rotations were measured by a Jasco P-1020 polarimeter (Jasco, Easton, MD, USA). IR spectra were recorded by a Bruker IFS-66/S FT-IR spectrometer (Bruker, Karlsruhe, Germany). Electrospray ionization (ESI) mass spectra were recorded on an Agilent 1200 Series HPLC system (Agilent Technologies, Santa Clara, CA, USA), equipped with a diode array detector and 6130 Series ESI mass spectrometer using an analytical Kinetex $\mathrm{C}_{18} 100 \AA$ A column $(100 \times 2.1 \mathrm{~mm}, 5 \mu \mathrm{m}$; Phenomenex, Torrance, CA, USA; solvent condition: from $10 \% \mathrm{MeOH} / \mathrm{H}_{2} \mathrm{O}$ to $100 \% \mathrm{MeOH}$ (gradient system, $0-20 \mathrm{~min}$ ); flow rate: $0.3 \mathrm{~mL} / \mathrm{min})$. Nuclear magnetic resonance (NMR) spectra were recorded by a Bruker AVANCE III $700 \mathrm{NMR}$ spectrometer operating at $700 \mathrm{MHz}\left({ }^{1} \mathrm{H}\right)$ and $175 \mathrm{MHz}\left({ }^{13} \mathrm{C}\right)$ (Bruker, Karlsruhe, Germany), with chemical shifts given in ppm ( $\delta$ ). The ${ }^{1} \mathrm{H}$ NMR spectrum of compound 5 was recorded using a Bruker AVANCE III HD 850 NMR spectrometer with a $5 \mathrm{~mm}$ TCI CryoProbe operating at $850 \mathrm{MHz}$, with chemical shifts given in ppm $(\delta)$. Prepar- 
ative high-performance liquid chromatography (HPLC) used a Waters 1525 Binary HPLC pump with Waters 996 Photodiode Array Detector (Waters Corporation, Milford, CT, USA). Semi-preparative HPLC used a Shimadzu Prominence HPLC System with SPD-20A/20AV Series Prominence HPLC UV-Vis Detectors (Shimadzu, Tokyo, Japan) and a Phenomenex Luna C18 column $(250 \times 10 \mathrm{~mm}, 5 \mu \mathrm{m}$; flow rate: $2 \mathrm{~mL} / \mathrm{min}$; Phenomenex, Torrance, CA, USA). Silica gel 60 (Merck, 70-230 mesh and 230-400 mesh) and RP-C18 silica gel (Merck, 40-63 $\mu \mathrm{m}$ ) were used for column chromatography. Merck precoated Silica gel F254 plates and RP-18 F254s plates (Merck, Darmstadt, Germany) were used for TLC. Spots were detected on TLC under UV light or by heating after spraying with anisaldehyde-sulfuric acid.

\subsection{Plant Material}

The fruits of M. alba were collected in China in January 2014. A voucher specimen (MA 1414) of the material was identified by one of the authors (K.H. Kim) and was placed in the herbarium of the School of Pharmacy, Sungkyunkwan University, Suwon, Korea.

\subsection{Extraction and Isolation}

M. alba fruits $(10.5 \mathrm{~kg})$ were dried at room temperature for one week and pulverized, and then immersed with a $70 \%$ ethanol $(2.5 \mathrm{~L})$ for two days three times at room temperature. The resultant ethanol extract was evaporated in vacuo, affording a crude brown ethanol extract $(1.4 \mathrm{~kg})$. The extract was dissolved in distilled water $(700 \mathrm{~mL})$ solvent-partitioned using hexane, $\mathrm{CH}_{2} \mathrm{Cl}_{2}, \mathrm{EtOAc}$, and $\mathrm{BuOH}$ to obtain the major four fractions, yielding 27.8, $85.3,32.9$, and $138.8 \mathrm{~g}$, respectively. The $\mathrm{CH}_{2} \mathrm{Cl}_{2}$ fraction was loaded onto a silica gel column (230-400 mesh) column and fractionated with $\mathrm{CH}_{2} \mathrm{Cl}_{2}-\mathrm{MeOH}$ (50:1-1:1, gradient system) to yield five fractions (A1-A5). Fraction A2 (2.3 g) was separated utilizing RP-C18 silica gel (230-400 mesh) column chromatography with $70 \%$ aqueous $\mathrm{MeOH}$ to give eleven fractions (B1-B11). Fraction B2 (753 mg) was subjected to silica gel column (230-400 mesh) eluted with $\mathrm{CH}_{2} \mathrm{Cl}_{2}-\mathrm{MeOH}$ (50:1-1:1, gradient system) to afford eight subfractions (B21-B28). Compounds $4\left(2.0 \mathrm{mg}, \mathrm{t}_{\mathrm{R}}=22.0 \mathrm{~min}\right.$, ESIMS (positive-ion mode) $\left.\mathrm{m} / \mathrm{z} 116.0[\mathrm{M}+\mathrm{H}]^{+}\right)$, $5\left(1.8 \mathrm{mg}, \mathrm{t}_{\mathrm{R}}=30.0 \mathrm{~min}\right.$, ESIMS (positive-ion mode) $\left.\mathrm{m} / \mathrm{z} 197.1[\mathrm{M}+\mathrm{H}]^{+}\right)$, and $6(2.9 \mathrm{mg}$, $\mathrm{t}_{\mathrm{R}}=45.5 \mathrm{~min}$, ESIMS (positive-ion mode) $\mathrm{m} / \mathrm{z} 137.0[\mathrm{M}+\mathrm{H}]^{+}$) were purified from subfraction B22 (84 mg) by semi-preparative reversed-phase HPLC using 35\% aqueous $\mathrm{MeOH}$. Subfraction B23 $(86 \mathrm{mg}$ ) was separated by semi-preparative reversed-phase HPLC using $40 \%$ aqueous $\mathrm{MeOH}$ to purify compounds $9\left(1.5 \mathrm{mg}\right.$, $\mathrm{t}_{\mathrm{R}}=45.5 \mathrm{~min}$, ESIMS (positive-ion mode) $\left.\mathrm{m} / \mathrm{z} 139.0[\mathrm{M}+\mathrm{H}]^{+}\right)$and $10\left(3.5 \mathrm{mg}, \mathrm{t}_{\mathrm{R}}=50.5 \mathrm{~min}\right.$, ESIMS (positive-ion mode) $\left.\mathrm{m} / \mathrm{z} 167.0[\mathrm{M}+\mathrm{H}]^{+}\right)$. Subfraction B24 $(108 \mathrm{mg})$ was fractionated by preparative reversedphase HPLC eluted with $\mathrm{MeOH}-\mathrm{H}_{2} \mathrm{O}$ (1:9-1:0, gradient system) to obtain five subfractions (B241-B245). Compounds 7 ( $2.4 \mathrm{mg}, \mathrm{t}_{\mathrm{R}}=15.0 \mathrm{~min}$, ESIMS (positive-ion mode) $\mathrm{m} / \mathrm{z} 171.1$ $\left.[\mathrm{M}+\mathrm{H}]^{+}\right)$and $8\left(2.9 \mathrm{mg}, \mathrm{t}_{\mathrm{R}}=32.5 \mathrm{~min}\right.$, ESIMS (positive-ion mode) $\left.\mathrm{m} / \mathrm{z} 169.0[\mathrm{M}+\mathrm{H}]^{+}\right)$ were isolated from subfraction B242 $(10 \mathrm{mg})$ by semi-preparative reversed-phase HPLC using $52 \%$ aqueous $\mathrm{MeOH}$. Compounds $1\left(3.0 \mathrm{mg}, \mathrm{t}_{\mathrm{R}}=37.0 \mathrm{~min}\right.$, ESIMS (positive-ion mode) $\left.\mathrm{m} / \mathrm{z} 225.1[\mathrm{M}+\mathrm{H}]^{+}\right), 2\left(4.2 \mathrm{mg}, \mathrm{t}_{\mathrm{R}}=40.0 \mathrm{~min}\right.$, ESIMS (positive-ion mode) $\mathrm{m} / \mathrm{z} 183.1$ $\left.[\mathrm{M}+\mathrm{H}]^{+}\right)$, and $3\left(2.8 \mathrm{mg}, \mathrm{t}_{\mathrm{R}}=45.0 \mathrm{~min}\right.$, ESIMS (positive-ion mode) $\mathrm{m} / \mathrm{z} 379.1[\mathrm{M}+\mathrm{H}]^{+}$) were obtained from subfraction B243 (14 mg) by semi-preparative reversed-phase HPLC using 59\% aqueous $\mathrm{MeOH}$. Fraction B8 (445 mg) was fractionated by silica gel column (230-400 mesh) with $\mathrm{CH}_{2} \mathrm{Cl}_{2}-\mathrm{MeOH}$ (30:1-1:1, gradient system) to afford nine subfractions (B81-B88). Compounds 11 (3.8 mg, $\mathrm{t}_{\mathrm{R}}=30.4 \mathrm{~min}$, ESIMS (positive-ion mode) $\mathrm{m} / \mathrm{z} 283.2[\mathrm{M}$ $\left.+\mathrm{H}]^{+}\right)$and $12\left(5.5 \mathrm{mg}, \mathrm{t}_{\mathrm{R}}=48.0 \mathrm{~min}\right.$, ESIMS (positive-ion mode) $\mathrm{m} / \mathrm{z} 431.3[\mathrm{M}+\mathrm{H}]^{+}$) were isolated from subfraction B83 $(38 \mathrm{mg})$ utilizing semi-preparative reversed-phase HPLC using $89 \%$ aqueous $\mathrm{MeOH}$. Four subfractions (B91-B94) were obtained from subfraction B9 (398 mg) using a silica gel column (230-400 mesh) with $\mathrm{CH}_{2} \mathrm{Cl}_{2}-\mathrm{MeOH}$ (50:1-1:1, gradient system). Subfraction B91 ( $25 \mathrm{mg}$ ) was separated by semi-preparative reversed-phase HPLC using $91 \%$ aqueous $\mathrm{MeOH}$ to obtain compounds $13\left(6.0 \mathrm{mg}\right.$, $\mathrm{t}_{\mathrm{R}}=42.0 \mathrm{~min}$, ESIMS (positiveion mode) $\left.\mathrm{m} / \mathrm{z} 429.3[\mathrm{M}+\mathrm{H}]^{+}\right)$and $\mathbf{1 4}\left(7.2 \mathrm{mg}, \mathrm{t}_{\mathrm{R}}=47.0 \mathrm{~min}\right.$, ESIMS (positive-ion mode) 
$\left.\mathrm{m} / \mathrm{z} 429.3[\mathrm{M}+\mathrm{H}]^{+}\right)$. Subfraction B93 (38 mg) was separated utilizing semi-preparative reversed-phase HPLC eluted with $92 \%$ aqueous $\mathrm{MeOH}$ to obtain compounds 15 (4.0 mg, $\mathrm{t}_{\mathrm{R}}=51.5 \mathrm{~min}$, ESIMS (positive-ion mode) $\left.\mathrm{m} / \mathrm{z} 431.3[\mathrm{M}+\mathrm{H}]^{+}\right), \mathbf{1 6}\left(6.7 \mathrm{mg}, \mathrm{t}_{\mathrm{R}}=53.0 \mathrm{~min}\right.$, ESIMS (positive-ion mode) $\left.\mathrm{m} / \mathrm{z} 431.3[\mathrm{M}+\mathrm{H}]^{+}\right)$, and $22\left(2.8 \mathrm{mg}, \mathrm{t}_{\mathrm{R}}=54.0 \mathrm{~min}\right.$, ESIMS (positive-ion mode) $\left.\mathrm{m} / \mathrm{z} 445.3[\mathrm{M}+\mathrm{H}]^{+}\right)$. Fraction B10 $(315 \mathrm{mg}$ ) was fractionated by a silica gel column (230-400 mesh) eluted with $\mathrm{CH}_{2} \mathrm{Cl}_{2}-\mathrm{MeOH}$ (100:1-1:1, gradient system) to give four subfractions (B101-B104). Compounds $17\left(3.6 \mathrm{mg}, \mathrm{t}_{\mathrm{R}}=43.0 \mathrm{~min}\right.$, ESIMS (positive-ion mode) $\left.\mathrm{m} / \mathrm{z} 445.4[\mathrm{M}+\mathrm{H}]^{+}\right)$and $\mathbf{1 8}\left(4.0 \mathrm{mg}, \mathrm{t}_{\mathrm{R}}=43.5 \mathrm{~min}\right.$, ESIMS (positive-ion mode) $\mathrm{m} / \mathrm{z} 445.4[\mathrm{M}+\mathrm{H}]^{+}$) were purified from subfraction B101 (23 $\left.\mathrm{mg}\right)$ utilizing semipreparative reversed-phase HPLC eluted with $88 \%$ aqueous $\mathrm{MeOH}$. Fraction A3 (1.8 g) was fractionated by a silica gel column (230-400 mesh) eluted with $\mathrm{CH}_{2} \mathrm{Cl}_{2}-\mathrm{MeOH}$ (100:1-1:1, gradient system) to acquire seven subfractions (A31-A37). Fraction A37 (330 mg) was further fractionated by a silica gel column (230-400 mesh) eluted with $\mathrm{CH}_{2} \mathrm{Cl}_{2}-\mathrm{MeOH}$ (30:1-1:1, gradient system) to give three subfractions (A371-373). Compounds 19 (6.3 mg, $t_{\mathrm{R}}=32.5 \mathrm{~min}$, ESIMS (positive-ion mode) $\left.\mathrm{m} / \mathrm{z} 593.4[\mathrm{M}+\mathrm{H}]^{+}\right), 20\left(4.2 \mathrm{mg}, \mathrm{t}_{\mathrm{R}}=51.0 \mathrm{~min}\right.$, ESIMS (positive-ion mode) $\left.\mathrm{m} / \mathrm{z} 702.5[\mathrm{M}+\mathrm{H}]^{+}\right)$, and $21\left(3.1 \mathrm{mg}, \mathrm{t}_{\mathrm{R}}=52.5 \mathrm{~min}\right.$, ESIMS (positive-ion mode) $\mathrm{m} / \mathrm{z} 593.4[\mathrm{M}+\mathrm{H}]^{+}$) were purified from subfraction A372 (139 mg) using semi-preparative reversed-phase HPLC eluted with 85\% aqueous $\mathrm{MeOH}$.

\subsection{RAW 264.7 Cells Culture}

A mouse macrophage cell line, RAW 264.7 (American Type Culture Collection, Rockville, MD, USA), was cultured in DMEM (Manassas, VA, USA) containing $4 \mathrm{mM}$ L-glutamine, antibiotics (1\% penicillin/streptomycin), and $10 \%$ fetal bovine serum in humidified air environment at $37^{\circ} \mathrm{C}$ in a $5 \% \mathrm{CO}_{2}$.

\subsection{Measurement of Viability of RAW 264.7 Cells}

RAW 264.7 cells $\left(3 \times 10^{4}\right.$ cells / well) were exposed to the indicated concentrations of compounds 1-22 for $24 \mathrm{~h}$ at $37{ }^{\circ} \mathrm{C}$ and incubated for an additional 40 min with Ez-Cytox solution (Daeil Lab Service Co., Seoul, Korea). Optical density at $450 \mathrm{~nm}$ was determined using a spectrophotometer microplate (PowerWave XS; Bio-Tek Instruments, Winooski, VT, USA).

\subsection{Measurement of NO Produced by RAW 264.7 Cells}

RAW 264.7 cells $\left(3 \times 10^{4}\right.$ cells / well) were exposed to the indicated concentrations of compounds 1-22 for $1 \mathrm{~h}$ and then incubated for an additional $24 \mathrm{~h}$ with LPS $(1 \mu \mathrm{g} / \mathrm{mL})$. At the end of the incubation, each culture supernatant was blended with the Griess reagent to determine NO production by RAW 264.7 cells. Optical density at $540 \mathrm{~nm}$ of the mixture was determined using a spectrophotometer microplate (PowerWave XS; Bio-Tek Instruments, Winooski, VT, USA).

\subsection{Western Blot Analysis}

RAW 264.7 cells $\left(4 \times 10^{5}\right.$ cells/well) were exposed to the indicated concentrations of compound 5 for $1 \mathrm{~h}$, and then incubated for an additional $24 \mathrm{~h}$ with LPS $(1 \mu \mathrm{g} / \mathrm{mL})$. At the end of the incubation, the RAW 264.7 cells were lysed with lysis buffer (Cell Signaling Technology, Beverly, MA, USA), supplemented with $1 \mathrm{mM}$ phenylmethylsulfonyl fluoride, for $20 \mathrm{~min}$. For Western blot analysis, $20 \mu \mathrm{g}$ of the total protein from the cell lysate was separated by $10 \%$ sodium dodecyl sulfate-polyacrylamide gel electrophoresis (SDS-PAGE). The proteins were electro-transferred to a polyvinylidene fluoride (PVDF) membrane. Each PVDF membrane was probed with primary antibodies (Cell Signaling Technology, Beverly, MA, USA) overnight, then incubated with horse radish peroxidase-conjugated anti-rabbit antibodies (Cell Signaling Technology, Beverly, MA, USA) for $1 \mathrm{~h}$ at room temperature, and visualized using an enhanced chemiluminescence detection reagent (GE Healthcare, Little Chalfont, UK). Western blot signals were detected by FUSION Solo Chemiluminescence System (PEQLAB Biotechnologie GmbH, Erlangen, Germany). 


\subsection{Statistical Analysis}

All assays were performed in triplicate and repeated at least three times. All data are presented as the mean \pm standard deviation (SD). Statistical significance was determined using one-way analysis of variance (ANOVA) and multiple comparisons with the Bonferroni correction. A $p$ value of $<0.05$ indicated statistical significance. All analyses were performed using SPSS Statistics ver. 19.0 (SPSS Inc., Chicago, IL, USA).

\section{Conclusions}

In summary, as part of an ongoing research project to discover bioactive natural products [45-50], phytochemical examination of the extract of $M$. alba fruits led to the isolation and identification of 22 compounds in the process of discovery of potential anti-inflammatory compounds. This study demonstrates that compound 5 inhibited NO production and iNOS and COX-2 in LPS-stimulated RAW 264.7 macrophages. At least in part, these inhibitory effects are mediated via inhibition of NF- $\mathrm{kB} / \mathrm{I}-\mathrm{kB} \alpha$ pathway (Figure 6). Thus, these findings supported the utilization of cyclo(L-Pro-L-Val) (5) as a favorable candidate for the treatment of inflammatory diseases.

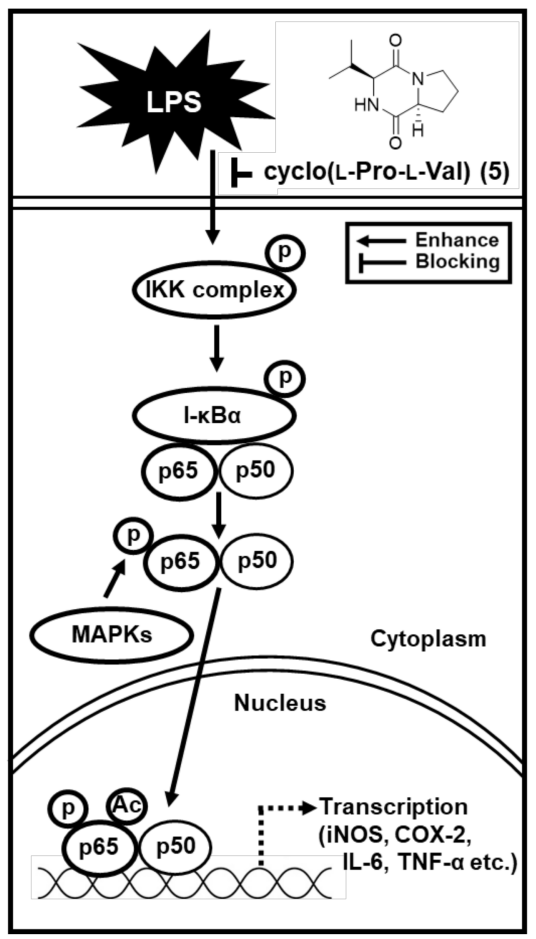

Figure 6. Schematic illustration of the mechanism for the potential role of compound 5 isolated from $M$. alba fruits in inflammatory responses. LPS, lipopolysaccharide; p, phosphorylated; IKK,

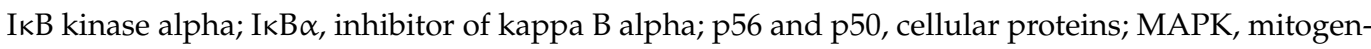
activated protein kinase; Ac, activated; TNF- $\alpha$, tumor necrosis factor alpha; IL-6, interleukin 6; COX-2, cyclooxygenase-2; iNOS, inducible nitric oxide synthase.

Supplementary Materials: The following are available online at https:/ / www.mdpi.com/article/ 10.3390/ijms22158120/s1, Figure S1: ${ }^{1} \mathrm{H}-\mathrm{NMR}$ spectrum of compound 1 (in $\mathrm{CD}_{3} \mathrm{OD}, 700 \mathrm{MHz}$ ); Figure S2: ${ }^{1} \mathrm{H}-\mathrm{NMR}$ spectrum of compound 2 (in $\mathrm{CD}_{3} \mathrm{OD}, 700 \mathrm{MHz}$ ); Figure S3: ${ }^{1} \mathrm{H}-\mathrm{NMR}$ spectrum of compound 3 (in $\mathrm{CD}_{3} \mathrm{OD}, 700 \mathrm{MHz}$ ); Figure S4: ${ }^{1} \mathrm{H}-\mathrm{NMR}$ spectrum of compound 4 (in $\mathrm{CD}_{3} \mathrm{OD}$, $700 \mathrm{MHz}$ ); Figure S5: ${ }^{13} \mathrm{C}-\mathrm{NMR}$ spectrum of compound 4 (in $\mathrm{CD}_{3} \mathrm{OD}, 175 \mathrm{MHz}$ ); Figure S6: ${ }^{1} \mathrm{H}-$ NMR spectrum of compound 5 (in $\mathrm{CD}_{3} \mathrm{OD}, 700 \mathrm{MHz}$ ); Figure S7: ${ }^{1} \mathrm{H}-\mathrm{NMR}$ spectrum of compound 5 (in $\mathrm{CDCl}_{3}, 850 \mathrm{MHz}$ ); Figure S8: ${ }^{1} \mathrm{H}-\mathrm{NMR}$ spectrum of compound 6 (in $\mathrm{CD}_{3} \mathrm{OD}, 700 \mathrm{MHz}$ ); Figure S9: ${ }^{1} \mathrm{H}-\mathrm{NMR}$ spectrum of compound 7 (in $\mathrm{CD}_{3} \mathrm{OD}, 700 \mathrm{MHz}$ ); Figure S10: ${ }^{1} \mathrm{H}-\mathrm{NMR}$ spectrum of compound 8 (in $\mathrm{CD}_{3} \mathrm{OD}, 700 \mathrm{MHz}$ ); Figure S11: ${ }^{1} \mathrm{H}-\mathrm{NMR}$ spectrum of compound 9 (in $\mathrm{CD}_{3} \mathrm{OD}$, $700 \mathrm{MHz}$ ); Figure S12: ${ }^{1} \mathrm{H}-\mathrm{NMR}$ spectrum of compound 10 (in $\mathrm{CD}_{3} \mathrm{OD}, 700 \mathrm{MHz}$ ); Figure S13: ${ }^{1} \mathrm{H}-$ 
NMR spectrum of compound 11 (in $\mathrm{CD}_{3} \mathrm{OD}, 700 \mathrm{MHz}$ ); Figure S14: ${ }^{1} \mathrm{H}-\mathrm{NMR}$ spectrum of compound 12 (in $\mathrm{CDCl}_{3}, 700 \mathrm{MHz}$ ); Figure S15: ${ }^{1} \mathrm{H}-\mathrm{NMR}$ spectrum of compound 13 (in $\mathrm{CDCl}_{3}, 700 \mathrm{MHz}$ ); Figure S16: ${ }^{1} \mathrm{H}-\mathrm{NMR}$ spectrum of compound 14 (in $\mathrm{CDCl}_{3}, 700 \mathrm{MHz}$ ); Figure S17: ${ }^{1} \mathrm{H}-\mathrm{NMR}$ spectrum of compound 15 (in $\mathrm{CD}_{3} \mathrm{OD}, 700 \mathrm{MHz}$ ); Figure S18: ${ }^{1} \mathrm{H}-\mathrm{NMR}$ spectrum of compound 16 (in $\mathrm{CDCl}_{3}$, $700 \mathrm{MHz}$ ); Figure S19: ${ }^{1} \mathrm{H}-\mathrm{NMR}$ spectrum of compound 17 (in $\mathrm{CD}_{3} \mathrm{OD}, 700 \mathrm{MHz}$ ); Figure S20: ${ }^{1} \mathrm{H}-\mathrm{NMR}$ spectrum of compound 18 (in $\mathrm{CD}_{3} \mathrm{OD}, 700 \mathrm{MHz}$ ); Figure S21: ${ }^{1} \mathrm{H}-\mathrm{NMR}$ spectrum of compound 19 (in $\mathrm{CD}_{3} \mathrm{OD}, 700 \mathrm{MHz}$ ); Figure S22: ${ }^{1} \mathrm{H}-\mathrm{NMR}$ spectrum of compound 20 (in $\mathrm{CD}_{3} \mathrm{OD}$, $700 \mathrm{MHz}$ ); Figure S23: ${ }^{1} \mathrm{H}-\mathrm{NMR}$ spectrum of compound 21 (in $\mathrm{CD}_{3} \mathrm{OD}, 700 \mathrm{MHz}$ ); Figure S24: ${ }^{1} \mathrm{H}-\mathrm{NMR}$ spectrum of compound 22 (in $\mathrm{CD}_{3} \mathrm{OD}, 700 \mathrm{MHz}$ ); Figure S25: The retention time of the L-FDAA derivatized L-Val as a standard; Figure S26: The retention time of the L-FDAA derivatized D-Val as a standard; Figure S27: The retention time of the L-FDAA derivatized L-Pro as a standard; Figure S28: The retention time of the L-FDAA derivatized D-Pro as a standard; Figure S29: The retention times of the L-FDAA derivatized Val/Pro derived from compound 5; Figure S30: The retention times of the L-FDAA derivatized Val derived from compound 5; Figure S31: The retention times of the L-FDAA derivatized Pro derived from compound 5.

Author Contributions: Conceptualization, K.S.K. and K.H.K.; formal analysis, D.L. and S.R.L.; investigation, D.L. and S.R.L.; writing — original draft preparation, D.L., S.R.L. and K.H.K.; writingreview and editing, K.H.K.; visualization, D.L. and S.R.L.; supervision, K.S.K. and K.H.K.; project administration, K.S.K. and K.H.K.; funding acquisition, K.S.K. and K.H.K. All authors have read and agreed to the published version of the manuscript.

Funding: This research was funded by the Basic Science Research Program through the National Research Foundation of Korea (NRF) funded by the Ministry of Education (2019R1F1A1059173). This work was also supported by a National Research Foundation of Korea (NRF) grant funded by the Korean government (MSIT) (grant numbers 2019R1A5A2027340 and 2021R1A2C2007937). This work was supported under the framework of international cooperation program managed by the National Research Foundation of Korea (NRF-2020K2A9A2A06037042).

Institutional Review Board Statement: Not applicable.

Informed Consent Statement: Not applicable.

Data Availability Statement: The data that support the findings of this study are available from the corresponding author upon reasonable request.

Conflicts of Interest: The authors declare no conflict of interest.

\section{References}

1. Bhatarrai, G.; Choi, J.-W.; Seong, S.H.; Nam, T.-J.; Jung, H.A.; Choi, J.S. Anti-inflammatory, Anti-glycation, Anti-tyrosinase and CDK4 Inhibitory Activities of Alaternin (=7-Hydroxyemodin). Nat. Prod. Sci. 2021, 27, 28-35. [CrossRef]

2. Rho, T.; Jeong, H.W.; Hong, Y.D.; Yoon, K.; Cho, J.Y.; Yoon, K.D. Identification of a novel triterpene saponin from Panax ginseng seeds, pseudoginsenoside RT8, and its antiinflammatory activity. J. Ginseng Res. 2020, 44, 145-153. [CrossRef] [PubMed]

3. Chang, Y.-S.; Jin, H.-G.; Lee, H.; Lee, D.-S.; Woo, E.-R. Phytochemical Constituents of the Root Bark from Morus alba and Their Il-6 Inhibitory Activity. Nat. Prod. Sci. 2019, 25, 268-274. [CrossRef]

4. Zhang, H.; Ma, Z.F.; Luo, X.; Li, X. Effects of mulberry fruit (Morus alba L.) consumption on health outcomes: A mini-review. Antioxidants 2018, 7, 69. [CrossRef]

5. Butkhup, L.; Samappito, W.; Samappito, S. Phenolic composition and antioxidant activity of white mulberry (Morus alba L.) fruits. Int. J. Food Sci. Technol. 2013, 48, 934-940. [CrossRef]

6. Gungor, N.; Sengul, M. Antioxidant activity, total phenolic content and selected physicochemical properties of white mulberry (Morus alba L.) fruits. Int. J. Food Prop. 2008, 11, 44-52. [CrossRef]

7. Yu, J.S.; Lim, S.H.; Lee, S.R.; Choi, C.-I.; Kim, K.H. Antioxidant and Anti-Inflammatory Effects of White Mulberry (Morus alba L.) Fruits on Lipopolysaccharide-Stimulated RAW 264.7 Macrophages. Molecules 2021, 26, 920. [CrossRef]

8. Razavi, R.; Molaei, R.; Moradi, M.; Tajik, H.; Ezati, P.; Yordshahi, A.S. Biosynthesis of metallic nanoparticles using mulberry fruit (Morus alba L.) extract for the preparation of antimicrobial nanocellulose film. Appl. Nanosci. 2020, 10, 465-476. [CrossRef]

9. Da Villa, G.; Ianiro, G.; Mangiola, F.; Del Toma, E.; Vitale, A.; Gasbarrini, A.; Gasbarrini, G. White mulberry supplementation as adjuvant treatment of obesity. J. Biol. Regul. Homeost. Agents 2014, 28, 141-145. [CrossRef]

10. Mahboubi, M. Morus alba (mulberry), a natural potent compound in management of obesity. Pharmacol. Res. 2019, 146, 104341. [CrossRef]

11. Lee, D.; Yu, J.S.; Lee, S.R.; Hwang, G.S.; Kang, K.S.; Park, J.G.; Kim, H.Y.; Kim, K.H.; Yamabe, N. Beneficial effects of bioactive compounds in mulberry fruits against cisplatin-induced nephrotoxicity. Int. J. Mol. Sci. 2018, 19, 1117. [CrossRef] 
12. Yu, J.S.; Lee, D.; Lee, S.R.; Lee, J.W.; Choi, C.-I.; Jang, T.S.; Kang, K.S.; Kim, K.H. Chemical characterization of cytotoxic indole acetic acid derivative from mulberry fruit (Morus alba L.) against human cervical cancer. Bioorg. Chem. 2018, 76, 28-36. [CrossRef]

13. Lee, S.R.; Park, J.Y.; Yu, J.S.; Lee, S.O.; Ryu, J.-Y.; Choi, S.-Z.; Kang, K.S.; Yamabe, N.; Kim, K.H. Odisolane, a novel oxolane derivative, and antiangiogenic constituents from the fruits of mulberry (Morus alba L.). J. Agric. Food Chem. 2016, 64, 3804-3809. [CrossRef]

14. Song, J.H.; Lee, D.; Lee, S.R.; Yu, J.S.; Jang, T.S.; Nam, J.W.; Kim, K.H.; Kang, K.S. Identification of bioactive heterocyclic compounds from mulberry and their protective effect against streptozotocin-induced apoptosis in INS-1 cells. Mol. Med. Rep. 2018, 17, 5982-5987. [CrossRef]

15. Kuang, H.X.; Yang, B.Y.; Xia, Y.G.; Feng, W.S. Chemical constituents from the flower of Datura metel L. Arch. Pharm. Res. 2008, 31, 1094-1097. [CrossRef]

16. Savidge, R.A.; Forster, H. Coniferyl alcohol metabolism in conifers-II. Coniferyl alcohol and dihydroconiferyl alcohol biosynthesis. Phytochemistry 2001, 57, 1095-1103. [CrossRef]

17. Li, L.Y.; Seeram, N.P. Further Investigation into Maple Syrup Yields 3 New Lignans, a New Phenylpropanoid, and 26 Other Phytochemicals. J. Agric. Food Chem. 2011, 59, 7708-7716. [CrossRef] [PubMed]

18. Delauney, A.J.; Verma, D.P.S. Proline Biosynthesis and Osmoregulation in Plants. Plant J. 1993, 4, 215-223. [CrossRef]

19. Adamczeski, M.; Reed, A.R.; Crews, P. New and Known Diketopiperazines from the Caribbean Sponge, Calyx cf. Podatypa. J. Nat. Prod. 1995, 58, 201-208. [CrossRef] [PubMed]

20. Choudhary, M.I.; Naheed, N.; Abbaskhan, A.; Musharraf, S.G.; Siddiqui, H.; Atta, U.R. Phenolic and other constituents of fresh water fern Salvinia molesta. Phytochemistry 2008, 69, 1018-1023. [CrossRef] [PubMed]

21. Kim, S.J.; Kim, M.C.; Um, J.Y.; Hong, S.H. The beneficial effect of vanillic acid on ulcerative colitis. Molecules 2010, 15, 7208-7217. [CrossRef]

22. Giovannini, C.; Straface, E.; Modesti, D.; Coni, E.; Cantafora, A.; De Vincenzi, M.; Malorni, W.; Masella, R. Tyrosol, the major olive oil biophenol, protects against oxidized-LDL-induced injury in Caco-2 cells. J. Nutr. 1999, 129, 1269-1277. [CrossRef]

23. Le, H.T.; Ha Do, T.; Minh, C.T.; Kim, T.H.; Van Kiem, P.; Thuan, N.D.; Na, M. Constituents from the stem barks of Canarium bengalense with cytoprotective activity against hydrogen peroxide-induced hepatotoxicity. Arch. Pharm. Res. 2012, 35, 87-92. [CrossRef]

24. Ul'chenko, N.; Gusakova, S.; Glushenkova, A. Oxygenated acids of the lipids of Onopordum acanthium seeds. Chem. Nat. Compd. 1993, 29, 447-450. [CrossRef]

25. Chaurasia, N.; Wichtl, M. Sterols and steryl glycosides from Urtica dioica. J. Nat. Prod. 1987, 50, 881-885. [CrossRef]

26. Zhang, X.; Julien-David, D.; Miesch, M.; Geoffroy, P.; Raul, F.; Roussi, S.; Aoudé-Werner, D.; Marchioni, E. Identification and quantitative analysis of $\beta$-sitosterol oxides in vegetable oils by capillary gas chromatography-mass spectrometry. Steroids 2005, 70, 896-906. [CrossRef]

27. Rodriguez, J.; Nunez, L.; Peixinho, S.; Jimenez, C. Isolation and synthesis of the first natural 6-hydroximino 4-en-3-one- steroids from the sponges Cinachyrella spp. Tetrahedron Lett. 1997, 38, 1833-1836. [CrossRef]

28. Zhao, C.C.; Shao, J.H.; Li, X.; Xu, J.; Zhang, P. Antimicrobial constituents from fruits of Ailanthus altissima SWINGLE. Arch. Pharm. Res. 2005, 28, 1147-1151. [CrossRef] [PubMed]

29. Kimura, Y.; Akihisa, T.; Yasukawa, K.; Takido, M.; Tamura, T. Structures of five hydroxylated sterols from the seeds of Trichosanthes kirilowii MAXIM. Chem. Pharm. Bull. 1995, 43, 1813-1817. [CrossRef]

30. Pettit, G.R.; Numata, A.; Cragg, G.M.; Herald, D.L.; Takada, T.; Iwamoto, C.; Riesen, R.; Schmidt, J.M.; Doubek, D.L.; Goswami, A. Isolation and structures of schleicherastatins 1-7 and schleicheols 1 and 2 from the teak forest medicinal tree Schleichera oleosa. J. Nat. Prod. 2000, 63, 72-78. [CrossRef] [PubMed]

31. Lei, X.; Li, J.; Liu, B.; Zhang, N.; Liu, H. Separation and identification of four new compounds with antibacterial activity from Portulaca oleracea L. Molecules 2015, 20, 16375-16387. [CrossRef]

32. Tsukamoto, S.; Tatsuno, M.; van Soest, R.W.; Yokosawa, H.; Ohta, T. New Polyhydroxy Sterols: Proteasome Inhibitors from a Marine Sponge Acanthodendrilla sp. J. Nat. Prod. 2003, 66, 1181-1185. [CrossRef]

33. Zhang, Z.-Y.; Ma, N.; Tao, L.-J.; Gong, X.-Y.; Ye, W.-C.; Wang, L. Linear peptides containing D-leucine with neuroprotective activities from the Leech Whitmania pigra Whitman. J. Nat. Prod. 2019, 82, 2349-2353. [CrossRef]

34. Lim, H.H.; Lee, S.O.; Kim, S.Y.; Yang, S.J.; Lim, Y. Anti-inflammatory and antiobesity effects of mulberry leaf and fruit extract on high fat diet-induced obesity. Exp. Biol. Med. 2013, 238, 1160-1169. [CrossRef]

35. Liu, C.-J.; Lin, J.-Y. Anti-inflammatory and anti-apoptotic effects of strawberry and mulberry fruit polysaccharides on lipopolysaccharide-stimulated macrophages through modulating pro-/anti-inflammatory cytokines secretion and Bcl-2/Bak protein ratio. Food Chem. Toxicol. 2012, 50, 3032-3039. [CrossRef] [PubMed]

36. Jung, S.; Lee, M.-S.; Choi, A.-J.; Kim, C.-T.; Kim, Y. Anti-inflammatory effects of high hydrostatic pressure extract of mulberry (Morus alba) fruit on LPS-stimulated RAW264. 7 cells. Molecules 2019, 24, 1425. [CrossRef] [PubMed]

37. Qian, Z.; Wu, Z.; Huang, L.; Qiu, H.; Wang, L.; Li, L.; Yao, L.; Kang, K.; Qu, J.; Wu, Y. Mulberry fruit prevents LPS-induced NF- $\mathrm{kB}$ / pERK/MAPK signals in macrophages and suppresses acute colitis and colorectal tumorigenesis in mice. Sci. Rep. 2015, 5, 17348. [CrossRef] [PubMed]

38. Kang, H.; Ku, S.-K.; Choi, H.; Bae, J.-S. Three diketopiperazines from marine-derived bacteria inhibit LPS-induced endothelial inflammatory responses. Bioorg. Med. Chem. Lett. 2016, 26, 1873-1876. [CrossRef] 
39. Tweedie, D.; Luo, W.; Short, R.G.; Brossi, A.; Holloway, H.W.; Li, Y.; Yu, Q.-s.; Greig, N.H. A cellular model of inflammation for identifying TNF- $\alpha$ synthesis inhibitors. J. Neurosci. Methods 2009, 183, 182-187. [CrossRef]

40. Pinsky, D.J.; Cai, B.; Yang, X.; Rodriguez, C.; Sciacca, R.R.; Cannon, P.J. The lethal effects of cytokine-induced nitric oxide on cardiac myocytes are blocked by nitric oxide synthase antagonism or transforming growth factor beta. J. Clin. Investig. 1995, 95, 677-685. [CrossRef] [PubMed]

41. Bhaskaran, N.; Shukla, S.; Srivastava, J.K.; Gupta, S. Chamomile: An anti-inflammatory agent inhibits inducible nitric oxide synthase expression by blocking RelA/p65 activity. Int. J. Mol. Med. 2010, 26, 935-940. [CrossRef]

42. Israël, A. The IKK complex, a central regulator of NF-кB activation. Cold Spring Harb. Perspect. Biol. 2010, 2, a000158. [CrossRef] [PubMed]

43. Oeckinghaus, A.; Ghosh, S. The NF-кB family of transcription factors and its regulation. Cold Spring Harb. Perspect. Biol. 2009, 1, a000034. [CrossRef] [PubMed]

44. Cuzzocrea, S.; Salvemini, D. Molecular mechanisms involved in the reciprocal regulation of cyclooxygenase and nitric oxide synthase enzymes. Kidney Int. 2007, 71, 290-297. [CrossRef] [PubMed]

45. Lee, S.; Lee, D.; Ryoo, R.; Kim, J.-C.; Park, H.B.; Kang, K.S.; Kim, K.H. Calvatianone, a sterol possessing a 6/5/6/5-fused ring system with a contracted tetrahydrofuran b-ring, from the fruiting bodies of Calvatia nipponica. J. Nat. Prod. 2020, 83, 2737-2742. [CrossRef]

46. Lee, S.R.; Kang, H.; Yoo, M.J.; Yu, J.S.; Lee, S.; Yi, S.A.; Beemelmanns, C.; Lee, J.; Kim, K.H. Anti-adipogenic pregnane steroid from a Hydractinia-associated fungus, Cladosporium sphaerospermum SW67. Nat. Prod. Sci. 2020, 26, 230-235. [CrossRef]

47. Lee, S.; Ryoo, R.; Choi, J.H.; Kim, J.-H.; Kim, S.-H.; Kim, K.H. Trichothecene and tremulane sesquiterpenes from a hallucinogenic mushroom Gymnopilus junonius and their cytotoxicity. Arch. Pharmacal Res. 2020, 43, 214-223. [CrossRef]

48. Jo, M.S.; Lee, S.; Yu, J.S.; Baek, S.C.; Cho, Y.-C.; Kim, K.H. Megastigmane derivatives from the cladodes of Opuntia humifusa and their nitric oxide inhibitory activities in macrophages. J. Nat. Prod. 2020, 83, 684-692. [CrossRef]

49. Yu, J.S.; Li, C.; Kwon, M.; Oh, T.; Lee, T.H.; Kim, D.H.; Ahn, J.S.; Ko, S.-K.; Kim, C.S.; Cao, S. Herqueilenone A, a unique rearranged benzoquinone-chromanone from the hawaiian volcanic soil-associated fungal strain Penicillium herquei FT729. Bioorg. Chem. 2020, 105, 104397. [CrossRef]

50. Ha, J.W.; Kim, J.; Kim, H.; Jang, W.; Kim, K.H. Mushrooms: An Important Source of Natural Bioactive Compounds. Nat. Prod. Sci. 2020, 26, 118-131. [CrossRef] 